\title{
The Relationship Between Residual Insulin Secretion and Metabolic Stability in Type 1 (Insulin Dependent) Diabetes
}

\author{
J. A. Lutterman, T. J. Benraad and A. van 't Laar \\ Department of Internal Medicine and Department for Experimental and Chemical Endocrinology, St. Radboud Hospital, \\ University of Nijmegen, The Netherlands
}

\begin{abstract}
Summary. The purpose of this study was to investigate whether the great differences in metabolic control between labile and stable insulin dependent juvenile diabetics could be explained by differences in residual pancreatic Bcell function. Nine labile diabetics, ten stable diabetics on one insulin injection a day and nine stable diabetics on two insulin injections a day were investigated during a $24-\mathrm{h}$ period during which they maintained their usual diet and insulin therapy. Serum C-peptide concentrations were measured after removal of proinsulin bound to insulin antibodies. The labile diabetics did not show any significant change in C-peptide concentrations despite great fluctuations in plasma glucose concentrations. In six patients with stable diabetes, C-peptide responses after the main meals could be demonstrated and there was a significant correlation between the concentrations of $\mathrm{C}$-peptide and glucose $(\mathrm{r}=0.85, \mathrm{p}<0.001)$. The other stable patients, having the same mean plasma glucose concentration and mean amplitude of glycaemic excursions, did not show any C-peptide response. It is concluded that persistent insulin secretion is not a prerequisite for metabolic stability. Severe lability, however, seems to occur only in the absence of residual insulin secretion.
\end{abstract}

Key words: Type 1 diabetes, labile and stable diabetes, radioimmunoassay of $\mathrm{C}$-peptide, serum $\mathrm{C}$ peptide levels, plasma glucose levels.

The significance of residual insulin secretion, established by the measurement of serum C-peptide levels, for the degree of metabolic control in Type 1 diabetes is not clear. In some studies no better metabolic control was found in patients in whom Cpeptide could be demonstrated $[1,2]$. Other authors have reported a positive correlation between the degree of metabolic control and C-peptide levels in groups of patients [3-8], but in individual patients this relationship was not always present. In almost all studies C-peptide immunoreactivity was measured by methods which include proinsulin bound to insulin antibodies. Moreover the measurements were performed in the fasting state or after non-physiological stimuli. In the present study C-peptide was measured after the removal of insulin antibodies in diabetics with stable and labile diabetes during the patients' usual diet and insulin therapy. The aim of the study was to investigate whether the great variation in metabolic stability could be explained by differences in residual insulin secretion.

\section{Patients and Methods}

\section{Patients}

All patients were Type I (insulin dependent) diabetics, selected as labile or stable patients on the basis of previously established criteria.

The diabetes was considered as labile if all of the following criteria during one year before the start of the study were fulfilled: (1) mean glycosuria $>30 \mathrm{~g} / 24 \mathrm{~h}$; (2) the occurrence of high $(>20 \mathrm{mmol} / \mathrm{l})$ and low $(<10 \mathrm{mmol} / \mathrm{l})$ plasma glucose concentrations at the same time on different days; (3) ketonuria $(++$ or +++ ) with high glycosuria on at least three visits, without intercurrent illness; (4) occurrence of spontaneous hypoglycaemic episodes; (5) adjustments of the insulin therapy in consequence of these complications; (6) visits to the outpatient clinic at least once a month and good co-operation.

Stable patients had to fulfill all of the opposite criteria during one year: (1) mean glycosuria $<30 \mathrm{~g} / 24 \mathrm{~h}$; (2) plasma glucose concentrations always lower than $15 \mathrm{mmol} / 1$; (3) no ketonuria; (4) no hypoglycaemic attacks; (5) a constant insulin dosage; (6) visits to the out-patient clinic at least once in six weeks and good co-operation.

Nine patients with labile diabetes were selected. Their mean $( \pm \mathrm{SD}$ ) age was $28.9 \pm 8.7$ years, duration of diabetes $11.1 \pm 4.2$ years and their mean percentage of ideal body weight was $98.8 \pm$ $17.9 \%$. The mean insulin dosage was $90 \pm 37 \mathrm{U} / 24 \mathrm{~h}(1.3 \pm$ $0.5 \mathrm{U} / \mathrm{kg}$ body weight), given in two injections a day as combinations of long and short acting insulin (usually Ultralente in the morning and Actrapid in the morning and evenings). They had attended the out-patient clinic 12 to 28 times during the year before the study. On 3-28 visits they had complained of unpredict- 


\section{LABILE DIABETES}
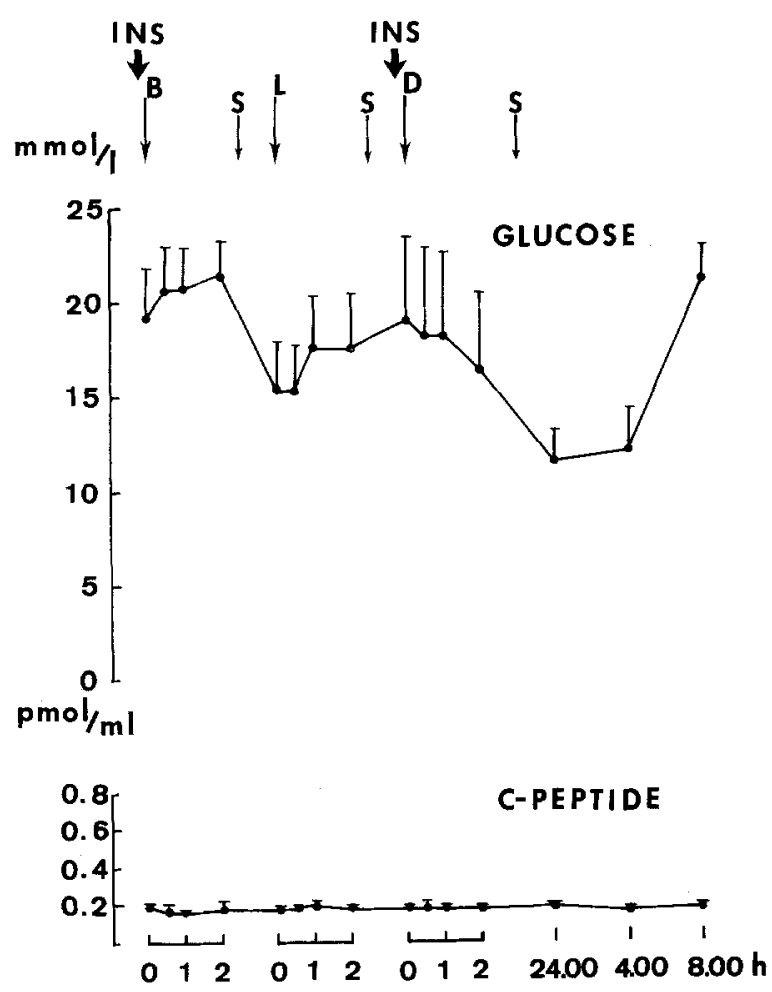

Fig. 1. Mean concentration ( \pm SEM) of plasma glucose and serum C-peptide in nine labile diabetics during $24 \mathrm{~h}$. Blood samples were taken just before breakfast (B), lunch (L) and dinner (D), $1 / 2,1$ and $2 \mathrm{~h}$ after these meals, and at 2400,0400 and $0800 \mathrm{~h}$. $\mathrm{S}=$ snack. The insulin injections are indicated by "INS"

able hypoglycaemic attacks and on 4-11 visits ketonuria in combination with glycosuria was found. Due to this the insulin dosage had to be changed 5-19 times. All efforts to achieve better metabolic control had failed without apparent cause.

Nineteen patients with stable diabetes were selected. Ten were treated with one injection a day of long acting insulin. Their mean age was $35.0 \pm 9.2$ years, duration of diabetes $10.4 \pm 7.5$ years and mean percentage of ideal bodyweight $104 \pm 5.2 \%$. The mean insulin dosage was $34 \pm 15 \mathrm{U} / 24 \mathrm{~h}(0.5 \pm 0.2 \mathrm{U} / \mathrm{kg}$ body weight $)$. The other nine patients with stable diabetes were treated with insulin twice a day. Their mean age was $32.4 \pm 9.0$ years, duration of diabetes $14.2 \pm 9.0$ years, their percentage of ideal bodyweight $102.2 \pm 8.5 \%$ and the insulin dosage was $63 \pm 22 \mathrm{U} / 24 \mathrm{~h}(0.9 \pm$ $0.3 \mathrm{U} / \mathrm{kg}$ body weight). Only the mean insulin dosage was significantly different between the groups.

\section{Design of the Study}

On the day of the study, after an overnight fast, the patients came to the ward early in the morning, where they stayed for $24 \mathrm{~h}$. Between the times of blood sampling they were encouraged to walk around. They received their usual diet and insulin therapy. In all patients the diet was given as three main meals and three snacks ( $\pm 20 \%$ of the calories was supplied as protein, $\pm 40 \%$ as fat and $\pm 40 \%$ as carbohydrate). Insulin was administered $15 \mathrm{~min}$ before breakfast and in patients treated with two injections a day 15 min before the evening meal. Blood for the determination of C-peptide and glucose was taken immediately before the insulin injections, before the main meals and at 30,60 and 120 min after the start of the meals, at 2400 and $0400 \mathrm{~h}$, and on the following morning in the fasting state.

\section{Laboratory Methods}

C-peptide concentration in serum was measured by radioimmunoassay using synthetic human C-peptide as standard, synthetic human ${ }^{125} \mathrm{~J}$-Tyr-C-peptide as tracer and antiserum M1230, obtained from Novo Industri, Denmark. Insulin antibodies were removed prior to the assay by precipitation with equal amounts polyethylene glycol (PEG 25\%) [9]. The final concentration of PEG in serum and in C-peptide standard solution was the same. The detection limit was $0.06 \mathrm{pmol} / \mathrm{ml}$. The PEG treatment of sera did not affect the accuracy of the assay. The intra-assay coefficient of variation for sera with low $(0.52 \mathrm{pmol} / \mathrm{ml})$ and high $(2.87 \mathrm{pmol} /$ $\mathrm{ml}) \mathrm{C}$-peptide concentration was $5.7 \%(n=10)$ and $4.4 \%(n=$ $10)$. The interassay coefficient of variation was 14.8 and $12.9 \%$ for the same sera. The recovery of $0.2-2.0 \mathrm{pmol} / \mathrm{ml} \mathrm{C}$-peptide was between 98 and $106 \%$. Serum dilution up to $1: 4$ did not affect the measurements. In normal lean subjects the mean ( \pm SD) fasting C-peptide concentration was $0.53 \pm 0.17 \mathrm{pmol} / \mathrm{ml}$ (range $0.28-0.86 \mathrm{pmol} / \mathrm{ml}, n=28$ ).

Plasma glucose was measured by the automated method of Hoffman [10]. The mean amplitude of glycaemic excursions was measured according to Service et al. [11]. Only excursions exceeding one SD of the mean plasma glucose concentration were considered.

\section{Statistics}

All results are presented as mean \pm SEM. For statistical evaluation Wilcoxon's test for unpaired data was used.

\section{Results}

\section{Labile Diabetics}

The mean plasma glucose concentration in the labile diabetics fluctuated widely without a clear relation to meals (Fig. 1). The mean amplitude of glycaemic excursions measured from the individual curves was $17.4 \pm 2.8 \mathrm{mmol} / \mathrm{l}$. The fasting C-peptide concentration was $0.19 \pm 0.03 \mathrm{pmol} / \mathrm{ml}$. Despite great fluctuations of the glucose concentrations the mean serum C-peptide concentration did not change significantly. In no patient was a variation coefficient of $15 \%$ exceeded, the value chosen as the limit for a significant change in concentration.

\section{Stable Patients}

In five patients on one insulin injection a day and in eight patients on two injections the mean fasting concentration $(0.18 \pm 0.02 \mathrm{pmol} / \mathrm{ml})$ did not change significantly during the $24 \mathrm{~h}$ (Fig. 2) and at no point was there a significant difference with the mean C-peptide concentration in the labile patients. All the other patients showed a C-peptide response after every main meal (Fig. 2) with mean levels (from $0.25 \pm$ $0.03 \mathrm{pmol} / \mathrm{ml}$ in the fasting state) of $0.50 \pm$ $0.08 \mathrm{pmol} / \mathrm{ml}$ after breakfast, $0.63 \pm 0.04 \mathrm{pmol} / \mathrm{ml}$ 
after lunch and $0.57 \pm 0.09 \mathrm{pmol} / \mathrm{ml}$ after dinner. In these subjects a significant correlation existed between the concentrations of C-peptide and glucose $(r=0.85, p<0.001)$. The sum of the increases of $C$ peptide concentration after each meal was significantly correlated with the mean $24 \mathrm{~h}$ plasma glucose concentration $(r=-0.79, p<0.05)$. Between the stable diabetics with and without $C$-peptide response there was no significant difference in mean age, percentage of ideal body weight, mean $24 \mathrm{~h}$ plasma glucose concentration and mean amplitude of glycaemic excursions. The six diabetics with C-peptide responses had diabetes for a shorter duration and needed a lower insulin dosage (Table 1).

\section{STABLE DIABETES}

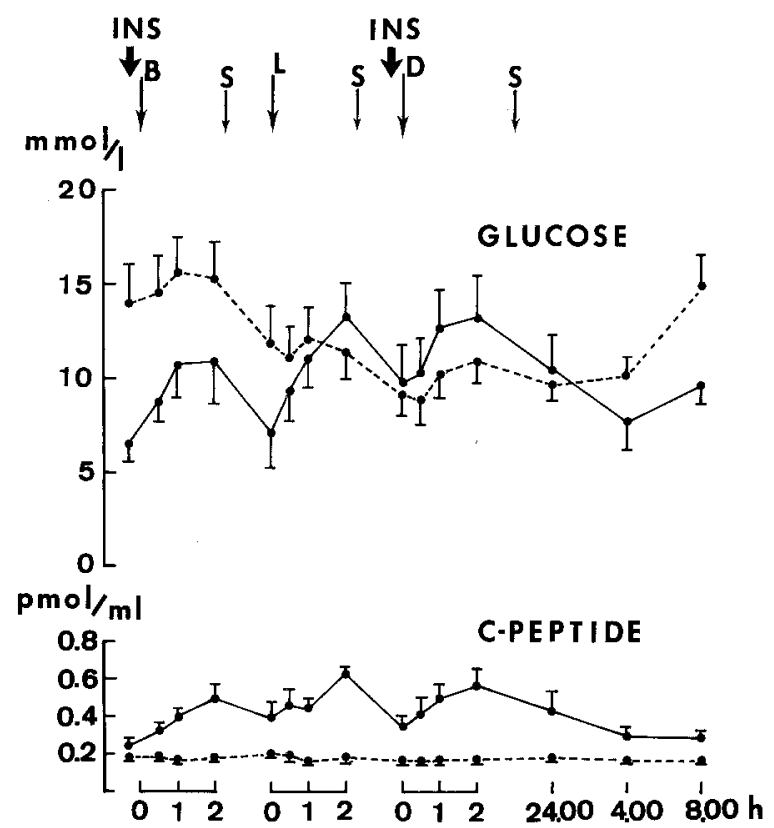

Fig. 2. Mean concentration ( \pm SEM) of plasma glucose and serum $\mathrm{C}$-peptide in the stable diabetics during $24 \mathrm{~h}$ with (solid line, $\mathrm{n}=6$ ) and without (broken line, $\mathrm{n}=13$ ) a C-peptide response after the main meals. Symbols as in Fig. 1. Only nine patients were treated with an evening injection of insulin (see text)

\section{Discussion}

Labile diabetes is characterised by great and unpredictable fluctuations in plasma glucose concentrations both during the day and from day to day, accompanied by a strong tendency to ketosis and to hypoglycaemic reactions, despite all attempts at the best possible treatment [12]. In stable diabetes the opposite is true. It is difficult to define stability and lability quantitatively. Of the criteria that we used each single one is not necessarily a reflection of metabolic (in)stability but we feel that all the criteria together are a valid translation of the descriptive definitions of lability and stability.

It was the purpose of the study to investigate the role of residual insulin secretion in metabolic control during everyday life. Therefore the usual meals of the subjects were chosen as B cell stimulation instead of articificial stimuli, such as glucagon injections. Moreover, the insulin secretion after meals corresponds very well with that after IV glucagon $[13,14]$.

Before the measurement of C-peptide insulin antibodies were precipitated by PEG $25 \%$. Heding et al. $[15,16]$ have demonstrated the existence of persistent proinsulin secretion in Type 1 diabetics even when insulin and C-peptide secretion were absent. This proinsulin is bound to insulin antibodies, which delays its clearance. The bound proinsulin reacts with C-peptide antisera and thus must be removed for a reliable C-peptide measurement. This has, however, not been done in studies on residual insulin secretion in labile and stable diabetics so far published.

The labile patients did not show any C-peptide response to changes in plasma glucose concentrations. Nevertheless measurable concentrations were present in all sera. Although a so-called zero value was also found by others $[18,19]$, this is difficult to explain. It is possible that a small and constant secretion of C-peptide was present. The fact that even during hypoglycaemic periods the C-peptide level did not fall, argues against this theory. Another possibility is that the C-peptide antiserum reacts with free proinsulin, which is not removed by PEG. However,

Table 1. Details of labile and stable diabetics with and without $\mathrm{C}$-peptide responses after meals (mean $\pm \mathrm{SEM}$ )

\begin{tabular}{|c|c|c|c|}
\hline & Labile patients & $\begin{array}{l}\text { Stable patients } \\
\text { with C-peptide }\end{array}$ & $\begin{array}{l}\text { Stable patients } \\
\text { without } \mathrm{C} \text {-peptide }\end{array}$ \\
\hline No of patients & 9 & 6 & 13 \\
\hline Age (years) & $28.9 \pm 2.9$ & $32.8 \pm 3.7$ & $34.3 \pm 2.5$ \\
\hline Ideal body weight $(\%)$ & $98.8 \pm 6.0$ & $100.5 \pm 2.8$ & $105 \pm 1.9$ \\
\hline Duration of diabetes (years) & $11.1 \pm 1.4$ & $5.5 \pm 1.4^{b}$ & $15.2 \pm 2.3$ \\
\hline Insulin dosage $(\mathrm{U} / 24 \mathrm{~h})$ & $90 \pm 12^{b}$ & $29 \pm 7^{\mathrm{b}}$ & $56 \pm 6$ \\
\hline Mean plasma glucose $(\mathrm{mmol} / \mathrm{l})^{a}$ & $17.8 \pm 1.6^{\mathrm{b}}$ & $10.0 \pm 1.4$ & $12.2 \pm 1.0$ \\
\hline Mean amplitude of glycaemic excursions $(\mathrm{mmol} / \mathrm{l})^{\mathrm{a}}$ & $17.4 \pm 2.8^{\mathrm{b}}$ & $7.4 \pm 0.8$ & $10.8 \pm 1.7$ \\
\hline
\end{tabular}

a Results of $24 \mathrm{~h}$ measurements ${ }^{\mathrm{b}} p<0.05$ versus other groups 
Kuzuya et al. [17] have shown that the free proinsulin concentration is too low to be measured with a Cpeptide antiserum that reacts less well with proinsulin than with C-peptide. The cross-reactivity of antiserum M1230 with proinsulin as compared to C-peptide is $11 \%$ on a molar base [18]. It has been suggested that $\mathrm{C}$-peptide antiserum reacts with plasma components other than C-peptide and proinsulin [18, 19]. However the exact cause of this remains unclear.

In several other studies labile and stable diabetics were investigated. Shima et al. [5] determined the degree of stability by the magnitude of the standard deviation of ten fasting plasma glucose concentrations. C-peptide immunoreactivity increased after oral glucose and during IV arginine in the stable insulin dependent diabetics but the seven most labile patients did not show a response. Reynolds et al. [3], using the same B cell stimulation, came to similar findings and these authors concluded that the difference between unstable and stable diabetics was partly explained on the basis of persisent insulin secretion in many, if not all, stable diabetics. Yue et al. [6] classified labile or non-labile patients according to their degree of metabolic control. After a $50 \mathrm{~g}$ oral glucose load, C-peptide response was absent not only in the labile patients but also in many stable diabetics. In these studies bound proinsulin was not removed before the C-peptide assay. Our results obtained under more normal conditions and after removal of insulin antibodies support the observations of Yue et al. [6].

Although the labile patients did not show any sign of functional B cell activity, this cannot be the only cause of lability, because in 13 of the 19 stable patients C-peptide response was also absent. However in six patients with stable diabetes C-peptide response was evident. In these patients the increases and decreases of plasma glucose were related to meals and there was a significant correlation between the concentrations of glucose and C-peptide, suggesting that the preserved $\mathrm{B}$ cell function contributed to the stability. However persistent insulin secretion is not a prerequisite for stability. The absence of persistent $\mathrm{B}$ cell function, nevertheless, seems to be associated with severe lability.

\section{References}

1. Eff Ch, Faber O, Deckert T (1978) Persistent insulin secretion, assessed by plasma C-peptide estimation in long-term juvenile diabetics with a low insulin requirement. Diabetologia 5: $169-172$

2. Madsbad S, McMair P, Faber OK, Binder C, Christansen C, Transbøl I (1980) Beta-cell function and metabolic control in insulin treated diabetics. Acta Endocrinol (Copenh) 93: 196-200
3. Reynolds C, Molnar GD, Horwitz DL, Rubstein AH, Taylor WF, Jiang NS (1977) Abnormalities of endogenous glucagon and insulin in unstable diabetes. Diabetes 26: 36-45

4. Grajwer LA, Pildes RS, Horwitz DL, Rubenstein AH (1977) Control of juvenile diabetes mellitus and its relationship to endogenous insulin secretion as measured by C-peptide immunoreactivity. J Pediatr 90: 42-48

5. Shima K, Tanaka R, Morishita S, Tarui S, Kumahara Y, Mishikawa M (1977) Studies on the etiology of "Brittle Diabetes". Relationship between daibetic instability and insulinogenic reserve. Diabetes 26: 717-725

6. Yue DK, Baxter RC, Turtle JR (1978) C-peptide secretion and insulin antibodies as determinants of stability in diabetes mellitus. Metabolism 27: 35-44

7. Gonen B, Goldman J, Baldwin D, Goldberg RB, Ryan WG, Blix PM, Schanzlin D, Fritz KJ, Rubenstein AH (1979) Metabolic control in diabetic patients. Effect of insulin-secretory reserve (measured by plasma C-peptide levels) and circulating insulin antibodies. Diabetes 28: 749-753

8. Gerbitz K-D, Kemmler W, Edelmann A, Summer J, Mehnert H, Wieland OH (1979) Free insulin, bound insulin, C-peptide and the metabolic control in juvenile onset diabetics: comparison of C-peptide secretors and non-secretors during 24 hours conventional insulin therapy. Eur J Clin Invest 9: 475-483

9. Nakagawa S, Nakayama H, Sasaki T, Yochino K, Yu YY, Shinozaki K, Aoki S, Mashimo K (1973) A simple method for the determination of serum free insulin levels in insulintreated patients. Diabetes 22: 590-600

10. Hoffman WS (1937) A rapid photoelectric method for the determination of glucose in blood and urine. J Biol Chem 120: $51-55$

11. Service FJ, Molnar GD, Rosevaer JW, Ackerman E, Gatewood LC, Taylor WT (1970) Mean amplitude of glycemic excursions, a measure of diabetic instability. Diabetes 19: 644-655

12. Molnar GD (1964) Observations on the etiology and therapy of "brittle" diabetes. Can Med Assoc J 18: 953-959

13. Faber DK, Binder C (1977) C-peptide response to glucagon. A test for the residual B-cell function in diabetes mellitus. Diabetes 26: 605-610

14. Hendriksen C, Faber OK, Binder C (1977) Prevalence of residual $\mathrm{B}$-cell function in insulin-treated diabetics evaluated by the plasma $\mathrm{C}$-peptide response to intravenous glucagon. Diabetologia 13: 615-619

15. Heding LG, Ludvigsson J (1977) Human proinsulin in insulintreated diabetics. Acta Paediatr Scand [Suppl] 270: 48-52

16. Heding LG (1978) Insulin, C-peptide and proinsulin in nondiabetcs and insulin-treated diabetics. Characterization of the proinsulin in insulin-treated diabetics. Diabetes 27: 178-183

17. Kuzuya H, Blix PM, Horwitz DL, Steiner DF, Rubenstein AH (1977) Determination of free and total insulin and C-peptide in insulin treated diabetics. Diabetes 26: 22-29

18. Faber OK, Binder C, Markussen J, Heding LG, Naithani VK, Kuzuya H, Blis P, Horwitz DL, Rubenstein AH (1978) Characterization of seven C-peptide antisera. Diabetes 27: 170-177

19. Heding LG (1975) Radioimmunological determination of human C-peptide in serum. Diabetologia 11: 541-548

Received: 3 March 1981

\author{
J. A. Lutterman \\ Department of Internal Medicine \\ St. Radboud Hospital \\ Geert Grooteplein 16 \\ NL-6500 HB Nijmegen, The Netherlands
}

